ENCYCLOPEDDIE Encyclopédie berbère

BERBERE

3 | 1986

3 | Ahaggar - Alī ben Ghaniya

\title{
Aïn el-Bey
}

G. Camps

\section{OpenEdition}

Journals

Édition électronique

URL : http://journals.openedition.org/encyclopedieberbere/837

DOI : $10.4000 /$ encyclopedieberbere.837

ISSN : 2262-7197

\section{Éditeur}

Peeters Publishers

\section{Édition imprimée}

Date de publication : 1 juillet 1986

Pagination : 331

ISBN : 2-85744-260-2

ISSN : 1015-7344

\section{Référence électronique}

G. Camps, « Aïn el-Bey », Encyclopédie berbère [En ligne], 3 | 1986, document A117, mis en ligne le 01 décembre 2012, consulté le 12 octobre 2020. URL : http://journals.openedition.org/ encyclopedieberbere/837 ; DOI : https://doi.org/10.4000/encyclopedieberbere.837

Ce document a été généré automatiquement le 12 octobre 2020

(c) Tous droits réservés 


\section{Aïn el-Bey}

\section{G. Camps}

1 Localité située à $15 \mathrm{~km}$ au sud de Constantine où fut établi au XIX siècle un pénitencier. Aujourd'hui un aéroport international assure les relations de Constantine avec les autres villes de l'Algérie et avec l'étranger. Sur le plan archéologique, les environs d'Aïn el-Bey sont connus pour l'existence de nombreuses sépultures paléoberbères qui furent fouillées très anciennement par un vétérinaire militaire, $\mathrm{Ph}$. Thomas. Ces fouilles, qui furent publiées en 1878, sont remarquables par les précisions qu'elles apportent, pratique peu courante à l'époque.

2 L'auteur reconnaît des dolmens, des tombes à fosse ou à ciste et des « cromlechs » qui sont des bazinas, dont certaines à carapace, ou de simples tumulus. Les entourages, en pierres plantées, sont circulaires, ovales et parfois rectangulaires. Les tombes fouillées, au nombre d'une quarantaine, avaient souvent été pillées antérieurement. Toutefois le fouilleur put constater la fréquence des inhumations multiples, successives, compte tenu de l'exiguïté des chambres funéraires. Les rares éléments du mobilier susceptibles de donner une indication chronologique se rapportent au royaume numide et au $\mathrm{I}^{\text {er }}$ siècle.

3 En fait les différentes nécropoles d'Aïn el-Bey (Djebel Si Tahar, Mzora Thour, Chabet Saïd, Drah Guelah) appartiennent au vaste ensemble mégalithique de la Numidie cirtéenne centré sur le Djebel Fortass (Ras el-Aïn Bou Merzoug, Sila, Sigus, Bou Chène...) auquel s'ajoutent ceux du Djebel Settas (Mahidjiba) et du Djebel Mazela (Bou Nouara*), mais elles comptent parmi les plus récentes. 


\section{BIBLIOGRAPHIE}

THOMAS Ph. Recherches sur les sépultures anciennes des environ? d'Aïn el-Bey. Congr. intern. des Sciences anthrop., Paris, 1878 (1880), p. 13-21.

GSELL S. Les monuments antiques de l'Algérie, 1901, t. I, p. 24-25.

INDEX

Mots-clés : Antiquité 